\title{
Managing Turkish debt: An OLG investigation of the IMF's fiscal programming model for Turkey
}

\author{
Ebru Voyvoda ${ }^{\mathrm{a}}$, Erinc Yeldan ${ }^{\mathrm{b}, *}$ \\ a Middle East Technical University, Department of Economics, 06108 Ankara, Turkey \\ ${ }^{\mathrm{b}}$ Biklent University, Department of Economics, 06800 Ankara, Turkey
}

Received 1 May 2004; received in revised form 18 November 2004; accepted 5 April 2005

Available online 24 May 2005

\begin{abstract}
In this paper we investigate the fiscal policy alternatives on domestic debt management, cohort welfare, and growth for the Turkish economy. We utilize a model of exogenous growth in the overlapping generations (OLG) tradition with intertemporally optimizing agents and open capital markets, calibrated to the Turkish economy in 1990s. We examine the macroeconomic effects of the current IMF-led austerity program driven by the objective of attaining primary fiscal surpluses and illustrate the sensitivity of the program targets to growth shocks. Our results suggest that the current fiscal program based on the primary surplus objective succeeds in containing the explosive dynamics of debt accumulation, and yet, the path of aggregate public debt as a ratio to GNP displays significant degree of inertia and would be brought down only gradually and slowly.
\end{abstract}

(C) 2005 Society for Policy Modeling. Published by Elsevier Inc. All rights reserved.

Keywords: Turkey; Fiscal policy; IMF austerity; Expansionary fiscal contraction; OLG models

After a decade of volatile and erratic growth, persistent high rates of inflation, a deteriorated fiscal performance and rapidly increasing debt burden, Turkey initiated an extensive stabilization program to restore its macroeconomic balances in December 1999. Backed and supervised closely by the International Monetary Fund (IMF), the program exclusively relied on a nominally pegged (anchored) exchange rate system for disinflation and targeted

\footnotetext{
* Corresponding author. Tel.: +90 3122901659.

E-mail addresses: voyvoda@metu.edu.tr (E. Voyvoda), yeldane@ bilkent.edu.tr (E. Yeldan).
} 
a series of austerity measures and structural reforms to restore the fiscal balances. Yet, just eleven months after launching the disinflation program Turkey experienced a severe financial crisis in November 2000, and finally declared the surrender of the pegged exchange rate system on February 2001. The stock markets, employment, production, finance, and the Turkish lira went into a downward spiral and the gross domestic product shrunk by $7.4 \%$ over 2001, the worst performance since World War II. In response to the crisis, and in order to reinvigorate the now-stalled free market reforms, a new standby agreement was signed with the IMF. ${ }^{1}$

The 2001 program, hailed as the Turkey's Program for Transition to a Strong Economy (TSEP) included the conventional IMF austerity measures: drastic cuts in public spending, monetary contraction, flexible exchange rate management, and reductions in wage remunerations and in public employment. In particular, the TSEP has targeted a primary fiscal surplus of $6.5 \%$ to the GNP every year until 2006, and aimed at reducing the outstanding net stock of debt to $63.9 \%$, by the end of that year. It has foreseen a real rate of growth of $5 \%$ for 2003, 2004, and 2005, and assumed an operative nominal rate of interest of $46 \%$ for $2003,32.4 \%$ for 2004 , and $27.4 \%$ for 2005 . The targeted end-of-year inflation of the wholesale prices has been set at $16.2 \%, 12 \%$, and $8 \%$ for the same years, respectively. Thus, the Program implicitly assumes a significant real rate of interest through its implementation.

The main motivation of the program was to reduce the fiscal repression in the commodity and asset markets. This, in turn, was observed to be the result of high costs of servicing the public debt, often at exorbitant interest rates. Thus, the program primarily aimed at providing a signal of confidence both to the domestic and international community suggesting that the Turkish fiscal authorities are adhering to the "proper mix of stabilization measures". The program identified the public budget primary surplus (net of interest costs) as a ratio to the GNP as the most crucial indicator of this confidence game. According to the program's officially stated rationale, as the non-interest expenditures are reduced and the primary surplus target (of $6.5 \%$ to the GNP) is attained, real rate of interest would fall, converging to its international counterparts. The fall in the real rate of interest would then stimulate private consumption and investment, fueling growth through a virtuous mechanism of crowding-in.

Traditionally, the Fund's stabilization policy advice is criticized based on its implementation of an inappropriate mix of austerity measures to correct for balance of payments difficulties. Often the Fund comes under criticism that it has a dogmatic preference for fiscal prudence, often ignoring the likely negative implications for economic growth, as well as the deterioration of income distribution, regressing the living conditions of the poor and the marginalized. The current program put into operation in Turkey, on the other hand, claims a pro-growth twist. Accordingly, the severe cuts in non-interest expenditures would reduce the interest rates and would be expected to generate growth through the above narrated mechanisms of crowding-out in reverse, a mechanism which can be identified with a non-conventional phrase: expansionary fiscal contraction. Thus, the current IMF-led austerity program in Turkey provides a crucial test on the expansionary attributes of such fiscal contraction, and will likely have a major impact on the Fund's credibility in its capacity as

\footnotetext{
1 The underlying elements of the disinflation program and the succeeding crises are discussed in detail in Akyüz and Boratav (2002), Alper and Öniş (2003), Ertugrul and Yeldan (2003), Ertugrul and Selcuk (2002), and Yeldan (2002).
} 
a policy advisor (and as the international lender of last resort) in the age of new financial architecture.

Mostly based on these motivations, many researchers and financial rating agencies conducted a series of programming exercises to monitor the Turkish fiscal sustainability and its debt burden in the short- to medium-run. However, such exercises are often restricted to a partial adjustment framework, and do not go beyond an accounting check between the real rate of growth of the GNP, the interest rate, and the debt to GNP ratio. In fact, what is perhaps most notably lacking in these exercises is a general equilibrium framework where all macroeconomic variables are resolved in a consistent (Walrasian) system of flow equations describing production, expenditures on consumption and investment both by the private and the public sectors, savings and asset accumulation, foreign economic relations, and fiscal balances together with debt dynamics.

In this paper we develop an overlapping generations (OLG), small open economy model of exogenous growth and study the effects of fiscal policies of the government under the constraints of debt servicing and a binding fiscal gap. The model developed has an OLG structure with 30 generations at any moment, optimally choosing lifetime consumption and saving paths. The growth process is characterized by the accumulation of physical capital and by labor augmenting technological progress.

We focus on two sets of issues: First, the model is calibrated to generate the approximate macroeconomic panorama of 1990s for the Turkish economy. We then study the specifics and the expected macroeconomic consequences of the current austerity program, TSEP, as implemented under close IMF supervision. Next, we investigate the adjustment patterns of the model economy under various growth shocks, focusing on macro variables such as production, investment and growth, as well as economic welfare across generations.

The paper is organized as follows: in the next section we provide a broad overview of the Turkish economy over the 1990s. Next, we discuss some of the key elements of the IMF's fiscal sustainability programming exercises, and highlight some of the recent studies in the Turkish literature as pertain to our analysis. The algebraic set up of the model is introduced in Section 3. In Section 4 we implement our policy simulation exercises. Section 5 summarizes and concludes.

\section{Deterioration of fiscal balances and the IMF's stabilization program}

Turkish fiscal balances suffered a severe setback and all key macro indicators deteriorated in the 1990s. Table 1 documents this erosion.

At a first glance, the table reveals that over the 1990s the Turkish growth experience has been on a fluctuating trend, with abrupt mini business cycles, especially during the course of the last four years of the decade. Concomitant with this observation is the cyclical behavior of consumption and investment. One of the major signs of vulnerability has been continued inflation. Price inflation, which rested at the plateau of 60-65\% in 1980s has accelerated after 1998 and reached the plateau of $75-80 \%$. One of the main reasons of the continued disequilibrium and persistent inflation rates in the Turkish economy has been identified as the deterioration in the fiscal balances and the consequent rise of the public sector borrowing requirement (PSBR). The table reflects that the PSBR to the GNP ratio stood around 12\% 
Table 1

Main economic indicators and public accounts, Turkey

\begin{tabular}{|c|c|c|c|c|c|c|}
\hline & 1990 & 1995 & 1999 & 2000 & 2001 & 2002 \\
\hline \multicolumn{7}{|l|}{ Real rate of growth in } \\
\hline GNP & 9.4 & 8.0 & -6.1 & 6.3 & -9.4 & 7.8 \\
\hline \multicolumn{7}{|l|}{ Fixed investment } \\
\hline Private & 20.6 & 9.8 & -17.8 & 15.9 & -34.8 & -4.9 \\
\hline Public & 6.7 & -7.6 & -8.7 & 19.6 & -22.0 & 14.5 \\
\hline Private consumption & 13.1 & 5.6 & -2.6 & 6.2 & -9.0 & 1.8 \\
\hline \multicolumn{7}{|l|}{ As ratio of GNP $(\%)$} \\
\hline Current account balance & -1.7 & -1.4 & -0.7 & -4.8 & 2.4 & -1.0 \\
\hline Public disposable income & 13.4 & 9.4 & 7.0 & 7.2 & 3.9 & 6.3 \\
\hline Public savings & 3.4 & -0.1 & -6.8 & -5.2 & -9.9 & -6.6 \\
\hline Public investment & 8.6 & 3.8 & 6.6 & 6.9 & 5.5 & 5.8 \\
\hline Public sector borrowing requirement & 7.4 & 5.2 & 15.3 & 12.5 & 16.4 & 12.6 \\
\hline Budget balance & -3.0 & -4.0 & -11.9 & -10.6 & -16.2 & -14.3 \\
\hline Outstanding domestic debt & 14.4 & 17.3 & 29.3 & 29.0 & 69.2 & 54.8 \\
\hline Interest expenditures on domestic debt & 2.5 & 6.0 & 12.7 & 15.0 & 22.2 & 18.8 \\
\hline Non-interest government expenditures & 13.7 & 21.8 & 22.4 & 20.9 & 22.0 & 23.3 \\
\hline \multicolumn{7}{|l|}{ Fragility indicators } \\
\hline Short term foreign debt/CB reserves $(\%)$ & 165.0 & 128.7 & 98.9 & 127.6 & 85.9 & 66.0 \\
\hline Currency substitution $^{\mathrm{a}}$ & 22.5 & 54.8 & 45.2 & 44.1 & 56.2 & 56.5 \\
\hline Net new domestic borrowing/domestic debt stock (\%) & 40.7 & 52.4 & 49.3 & 37.1 & 70.2 & 15.9 \\
\hline \multicolumn{7}{|l|}{ Macroeconomic prices } \\
\hline Annual inflation rate $(\mathrm{WPI})^{\mathrm{b}}$ & 48.6 & 64.9 & 66.5 & 32.1 & 88.1 & 31.2 \\
\hline Nominal depreciation of the TL/US\$ & 22.9 & 53.5 & 61.0 & 23.2 & 114.2 & 13.2 \\
\hline Nominal interest rate on GDIs ${ }^{c}$ & 52.8 & 124.2 & 100.9 & 39.7 & 99.6 & 63.6 \\
\hline Real interest rate on GDIs ${ }^{\mathrm{d}}$ & 2.8 & 36.0 & 20.7 & 5.7 & 6.1 & 24.6 \\
\hline
\end{tabular}

Sources: SPO Main Economic Indicators; Undersecretariat of Foreign Trade and Treasury Main Economic Indicators.

${ }^{\text {a }}$ Ratio of foreign exchange deposits to total deposits of residents.

b Change in whole sale prices, end-of-year values.

c Weighted average of interest on government debt instruments (GDIs).

${ }^{\mathrm{d}}$ Deflated by the WPI.

on average between 1990 and 1999. Throughout this period, the budget deficit has been the main actor in the accumulation of PSBR.

The stock of domestic debt was only $6 \%$ of the GNP in 1989, just when the liberalization of the capital account was completed. It grew rapidly, and by the end of 2001 this ratio reached to $69.2 \%$. Interest costs on domestic debt grew to $22 \%$ of the GNP in the same year, increasing almost 10 -folds in real terms over the decade. ${ }^{2}$ The rise in the interest expenditures claimed almost all of the public sector disposable income in 2001. In fact, the fiscal authorities were trapped to such an extent that the targeted expenditures on interest

\footnotetext{
${ }^{2}$ See Undersecreteriat of Treasury, http://www.treasury.gov.tr.
} 


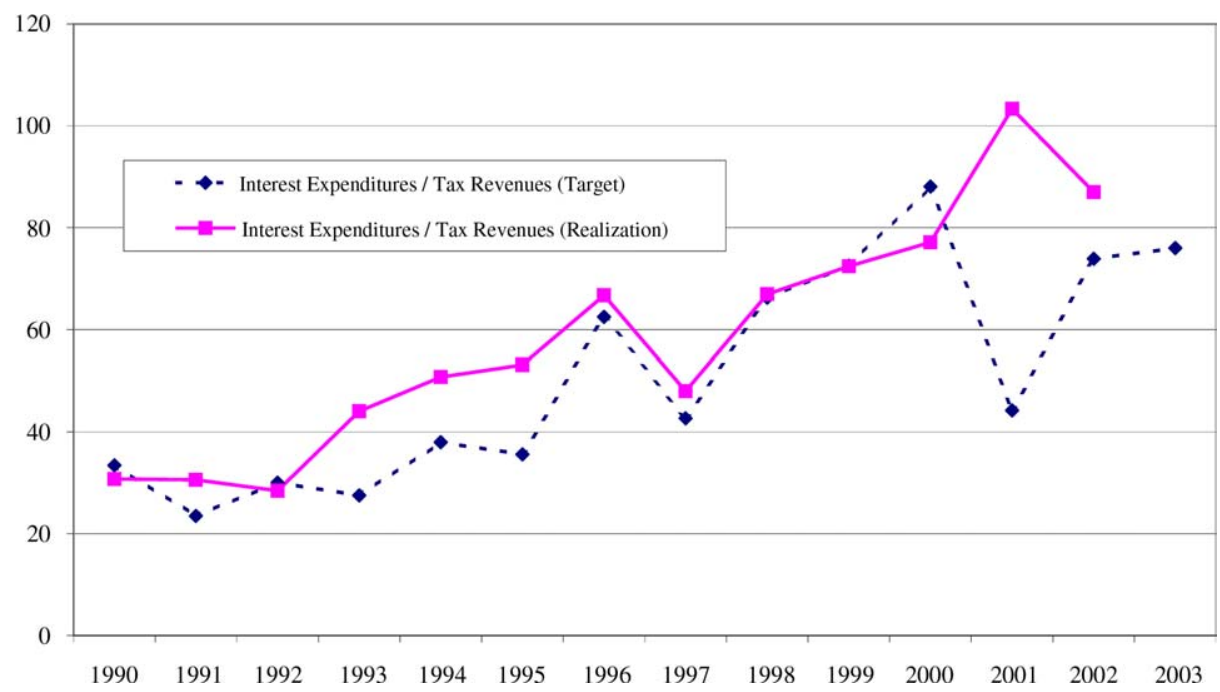

Fig. 1. Interest expenditures/tax revenues (\%) target and realization.

could not have been brought under control throughout the decade. In Fig. 1 we portray the paths of both the targeted and the realized values of the claims on tax revenues by interest costs. Clearly, Turkish fiscal revenues suffered a severe leakage from the expanding interest cost bill. In this regard, the central budget in Turkey has lost its instrumental role of social infrastructure development and long term growth, and became trapped to the dictates of domestic debt roll-over under a borrowing scheme of very high real rates of interest.

The underlying characteristic of the domestic debt management was its extreme shorttermism. Net new domestic borrowings, as a ratio to the stock of domestic debt continued at a pace of above $50 \%$ for most of the decade. Thus, the public sector was trapped in a short term rolling of debt, a phenomenon characterized as Ponzi-financing in the fiscal economics literature. ${ }^{3}$

The IMF's fiscal austerity program was first introduced in May 2001, just after the February 2001 financial crash. It was then expanded both in detail and time coverage. The program aimed at reducing the net consolidated public debt stock $^{4}$ to $63.9 \%$ of the GNP by 2006, from its level of $81.3 \%$ in 2002. Assuming an annual real rate of growth in the GNP by 5\% 2003 through 2006, the program targets a $6.5 \%$ surplus in the ratio of the aggregate public sector fiscal balance to the GNP $(5.4 \%$ in the ratio of the consolidated budget of the central government to the GNP). The basic macroeconomic targets and the key macroeconomic prices of the IMF program are summarized in Table 2.

\footnotetext{
${ }^{3}$ See Akyüz and Boratav (2002), Boratav, Yeldan, and Köse (2002), Yeldan (2002), and Cizre-Sakallığlu and Yeldan (2000) for a thorough overview of the post-1990 Turkish macroeconomic history. For the deterioration of fiscal balances see San (2002), Konukman, Aydın, and Oyan (2000), Özatay (1999), and Türel (1999).

4 The net consolidated public debt stock can be found by subtracting the deposits of the Treasury at the Central Bank and the Central Bank's net foreign assets from the gross public debt stock.
} 
Table 2

The IMF program: macro variables and price targets

\begin{tabular}{|c|c|c|c|c|c|c|}
\hline & 2001 & 2002 & 2003 & 2004 & 2005 & 2006 \\
\hline GNP growth rate & -8.5 & 3.0 & 5.0 & 5.0 & 5.0 & 5.0 \\
\hline Public sector primary balance & 5.7 & 6.5 & 6.5 & 6.5 & 6.5 & 6.3 \\
\hline Debt stock of the public sector/GNP (\%) & 92.2 & 81.3 & 73.3 & 69.4 & 66.5 & 63.9 \\
\hline \multicolumn{7}{|l|}{ Macro prices } \\
\hline Inflation & 68.5 & 35.0 & 20.0 & 12.0 & 8.0 & 5.0 \\
\hline Nominal interest rate on domestic debt & 99.7 & 69.6 & 46.0 & 32.4 & 27.4 & 23.9 \\
\hline Ex-ante real interest rate on domestic debt & 18.5 & 25.6 & 21.7 & 18.2 & 18.0 & 18.0 \\
\hline
\end{tabular}

We now turn to a brief account of the concept of debt sustainability, as the term will play a central role in our analysis.

\section{The IMF's vision of fiscal sustainability and solvency in the Turkish context}

Fiscal policy, sustainability and solvency have come to the forefront of stabilization policy in the recent years. The questions of whether a given level of debt is "sustainable" and/or whether large and persistent deficits will lead a government to default became common concerns for both the developed and the less-developed countries. ${ }^{5}$

The theoretical literature emphasizes the intertemporal budget constraint as well as the flow-budget constraint of the government, and focuses on whether current fiscal policy can be continued into the distant future without threatening government solvency. Yet, at the level of empirical policy analysis, the term "fiscal sustainability" remains highly controversial, and each empirical study often develops its own definition of the concept and derive its conclusions accordingly.

In its a broader policy approach in gauging whether a fiscal position is sustainable, the IMF is observed to adhere to the following steps ${ }^{6}$ : (i) based on the available macro-data, a projection with a five-year horizon is made assuming that the current fiscal policy is to be continued. This is regarded as the benchmark scenario. (ii) From this projection, a path for debt dynamics is generated and its sustainability is assessed. It is possible that different criteria are used for sustainability, but an increasing debt ratio is usually regarded as a cause for concern. (iii) If the path for debt dynamics is indicated as "unsustainable", an alternative scenario is prepared, making necessary corrections on fiscal policy variables, which will typically define a "stable path" over the medium-term. Exclusive attention is

\footnotetext{
${ }^{5}$ Corsetti and Roubini (1991) and Chalk and Hemming (2000) focus on fiscal sustainability in the OECD economies and come up with rather mixed results. After the Stability Growth Pact and the Maastricht Treaty fixing maximum reference values for the deficit (3\% of GDP) and net public debt (60\% of GDP), the budgetary discipline in Europe has been a matter of increasing concern. See Buiter (2003). The sustainability of the fiscal policy as well as the solvency of the governments in the LDC's have, not surprisingly, received the highest attention both from the academia and the international organizations such as the IMF and the World Bank. A few to mention among many are Buiter and Patel (1992) on India, Gerson and Nellor (1997) on Philippines, Bascard and Razin (1997) on Indonesia, and Agénor (2001) on Ghana and Turkey.

6 See, e.g., Chalk and Hemming (2000) and Agénor and Montiel (1999, chap.13). The IMF's official programming model, known as the Polak model, has recently celebrated its 40th year. See Polak (1997).
} 
usually directed on the adjustment of the primary balance in order to meet the debt target and the fiscal measures that can generate the warranted adjustment. ${ }^{7}$

In the Turkish context, given the macro targets stated in the previous section (see Table 2 above), it has been a routine accounting exercise to "check" the sustainability of the Turkish fiscal position by conducting various combinations of growth, interest rate, and primary surplus. Under one such study, for instance, Agénor (2001) reports that with an output growth rate of $5 \%$, a real interest rate of $12 \%$, and an inflation rate of $5 \%$, a primary surplus of $3.5 \%$ to the GNP would be needed to stabilize the Turkish debt to GNP ratio at $60 \%$. Based on his counter-factual scenarios, Agénor further reports that an additional 1 percentage point of primary surplus would be needed for each 2 percentage points of higher real interest rates.

More recently, Keyder (2003) also carried out a similar exercise and, using detailed fiscal data, concluded that Turkey's debt would come out to be sustainable on the condition that the real interest rate is reduced to $15 \%$, or less. Noting that at the time of her writing (March, 2003), the weighted average real interest rate was around $25 \%$, Keyder recommended strict continuation of the austerity policies programmed.

On the other hand, Akçay, Alper, and Özmucur (2002) investigated the relationship between fiscal sustainability, inflation, and budget deficits. Using time series econometrics, they concluded that the Turkish debt to GNP discloses an unsustainable fiscal outlook over the 1970-2000 period, and that over a forward-looking time horizon, a significant policy reversal towards austerity is necessary. In addition, various financial institutions and rating agencies carried out similar exercises almost on a monthly basis in their close monitoring of the Turkish fiscal stance. Under such exercises, various combinations of low/high rates of growth and the real interest are contrasted against a "plausible" benchmark scenario, and the resultant debt to GNP ratio is reported (see also IMF, 2000; World Bank, 2000; and the Undersecretariat of Treasury, 2003).

What is perhaps lacking in these "accounting exercises" is a general equilibrium framework where all macroeconomic variables are resolved in a consistent system of simultaneous equations. In fact, the crucial critique of the accounting exercises based on a partial adjustment framework is that they take no account of the general equilibrium effects of the fiscal policy itself on the macro economy at large, through interest rates, output, the saving-investment gap, and the current account balance. ${ }^{8}$ To analyze such effects, one would ideally use an economic model that explicitly relates the fiscal policy variables to (presumably) endogenous variables such as the real interest rates, wages, production, private and public expenditures on consumption and investment, and the foreign trade.

In the remaining pages of this paper we develop an intertemporal daynamic model in the overlapping generations (OLG) tradition, and utilize it as a laboratory device to study the effects of various growth shocks to such macro economic indicators as the fiscal

\footnotetext{
7 The IMF also claims that it pays considerable attention to the external sustainability as well, with a methodology followed that is analogous to the fiscal sustainability approach. In theory, there is no clear linkage between the external sustainability and the fiscal sustainability.

8 Agénor (2001) lists the limitations of the accounting approach as follows: (i) the a priori assumption about the definition of a "sustainable" fiscal policy is arbitrary, (ii) the framework lacks simultaneous determination of the crucial variables it uses, (iii) it focuses on a static flow-budget constraint whereas the government budget also has an intertemporal dimension, (iv) the lender's decision is not explicit.
} 
balances, real output, accumulation, factor prices, the external economy, and inter-temporal social welfare over a medium-long time horizon. We proceed by introducing the analytical structure of our model in the next section.

\section{The algebraic structure of the OLG model}

The model is based on Modigliani's "life-cycle" theory. Agents save and dissave at different stages of their lives to smooth consumption. The OLG structure characterizes generations not only by their age, but also by their wealth-endowment. In each period agents will be at different stages of their lifetime planning, and therefore, will be affected differently by any policy action taken by the government.

The model is a small-open economy version of Auerbach and Kotlikoff (1987), Mérette (1998) and Hviding and Mérette (1998). The economy consists of overlapping generations of finite-lived individuals who are assumed to have 30 periods, starting from the moment they enter the workforce. ${ }^{9}$ During the first 24 periods, the individual works, receives wage income and profits, which she divides between consumption, taxes on labor and capital incomes, and savings. In the last 6 periods, the agent is retired and consumes her accumulation of assets. Households are assumed rational, having perfect foresight. Labor supply is inelastic and no bequest motives are considered.

The technology is given by a standard Cobb-Douglas production function to produce a single commodity using capital and effective labor. Output is either consumed by domestic households or exported. Government generates revenues through taxation of both types of factor incomes, issues domestic and foreign debt, and administers public expenditures.

Financing of loanable funds for capital accumulation is secured by a financial intermediary. The intermediary collects domestic and foreign savings as well as the interest on previously issued government debt, and disposes off its aggregate funds among: (i) new physical capital accumulation, (ii) interest payments on domestic and foreign debt, and (iii) the public sector borrowing requirement. The intermediary has no independent objective function; nor any incentives for positive profits, and it simply acts as a means of collecting and re-distributing the loanable funds.

The algebraic structure of the model can be separated into several sets of equations relating to household behavior, production sector, government, the financial intermediary, the foreign sector and the aggregation and equilibrium conditions. We discuss each of these sets in turn.

\subsection{Households}

In what follows, subscript $t$ stands for the period and subscript $g$ stands for the age group. Assuming that every agent enters the workforce at the age of 16, retires at the age of 64, and lives until the age 76, $g=1$ refers to age group 16-17 years old, and $g=30$ refers to age group 74-75 years old. Population growth rate is assumed away.

\footnotetext{
${ }^{9}$ During childhood, young are assumed to be fully dependent on their parents to which they neither constitute extra burden nor provide any utility. Therefore, childhood period is left out of the analysis.
} 
We work with a representative agent for each of the 30 generations in the economy. Each individual, once entered into the workforce, derives utility from consuming $c c_{g, t}$ units of consumption good living her gth age at time $t$. Domestic good and imports form a consumption composite along a convex isoquant within a given substitution elasticity.

An agent entering the workforce at time $t$ is assumed to maximize an additively seperable form of utility function, with a generic form:

$$
U_{t}\left(c c_{1, t}, c c_{2, t+1}, \ldots, c c_{G, t+G-1}\right)=\sum_{g=1}^{G} \beta^{g-1} u\left(c c_{g, t+g-1}\right), \quad G=30
$$

Here $\beta$ is the discount factor, $0<\beta<1$, and $u(c c)$ is the current period utility function. ${ }^{10}$ Specifically, we use the following constant elasticity of substitution (CES) type utility function for the current period utility function $u$ :

$$
u\left(c c_{g, t}\right)=\frac{1}{1-(1 / \gamma)} c c_{g, t}^{1-(1 / \gamma)}
$$

where $c c_{g, t}$ is the consumption of an individual member of age group $g$ at time $t$, and $\gamma$ is the intertemporal elasticity of substitution. Leisure does not enter the utility function as we abstain from issues of labor participation and treat supply of labor as exogenous.

Optimization problem of the representative agent is subject to the physical wealth accumulation conditions. The current-period budget constraint of a member of the workforce at time $\mathrm{t}$ is given by:

$$
\begin{aligned}
a_{g+1, t+g}-a_{g, t+g-1}= & \left(1-\tau_{i}\right)\left[\left(1-\tau_{w}\right) w_{t+g-1} e_{g, t+g-1}\right. \\
& \left.+\left(1-\tau_{r}\right) r_{t+g-1} a_{g, t+g-1}\right]-c_{g, t+g-1}
\end{aligned}
$$

where $a_{g, t}$ is the physical wealth asset of an individual of age $g$ at time $t, w_{t}$ is the effective wage rate, and $e_{g, t}$ represents the technology "embodied" in the age group $g$. The term $r_{t}$ is the interest rate and $\tau_{i}, \tau_{w}$, and $\tau_{r}$ are tax rates on aggregate gross income, wages, and profits, respectively.

\subsection{The production sector}

Firms face competitive output and input markets to maximize profits. The representative firm's production technology is represented by a Cobb-Douglas production function with physical capital and effective labor force.

We specify an exogenous technological improvement, which is of the "labor augmenting" type. Every generation entering the workforce has a higher stock of technological knowledge than the previous one and thus becomes more productive by a constant factor, $\varphi$ :

$$
e_{1, t}=(1+\varphi) e_{1, t-1}
$$

\footnotetext{
10 The utility function $u($.$) is continuously differentiable, strictly increasing, strictly concave and homothetic.$ The homotheticity of $u$ allows a balanced growth path under labor-augmenting technology. See Caballé (1998).
} 
An agent, once endowed with the technological know-how, maintains her abilities throughout her lifespan. Factor demands are obtained from profit maximization decision of the firms by paying each factor its marginal product.

\subsection{Government}

In the current model, our analysis is focused on government spending behavior and accumulation of debt. We hypothesize that the government spends on its consumption, levies taxes on both types of income, pays interest on its debt, and borrows to finance any excess of current spending over current revenues. The government's single period budget identity is given by:

$$
B_{t+1}-B_{t}=r_{t} B_{t}+G_{t}-T_{t}
$$

where $B_{t}$ is the outstanding government debt and $T_{t}$ is the total tax revenues of the government at time $t . \mathrm{G}_{\mathrm{t}}$ represents total government expenditures. It is assumed that the government has no other income than what it collects through general taxes and does not invest in physical capital. ${ }^{11}$

\subsection{The intermediary}

All expenditures on capital accumulation are mediated through an artificial borrowinglending structure called the intermediary. The intermediary acts as an accounting identity, which accumulates the loanable funds:

$$
\mathrm{RI}_{t}=S_{t}^{P}+r_{t} B_{t}+r_{t} K_{t}+S_{t}^{F}
$$

where $S_{t}^{P}$ and $S_{t}^{F}$ represent the aggregate savings by domestic residents and foreigners, respectively. The amount of $r_{t} B_{t}$ gives the interest earnings of the intermediary on current debt of the government, and $r_{t} K_{t}$ gives the rent on capital stock used in production.

The intermediary disposes its funds, $\mathrm{EI}_{t}$ on the interest payments for servicing its foreign and domestic lenders, to meet the investment demand for physical capital, and to purchase newly issued government debt:

$$
\mathrm{EI}_{t}=I_{t}+r_{t} A_{t}+r_{t} B I_{t}^{F}+D_{t}
$$

Here, $A_{t}=\sum a_{g, t}$ represents the aggregate stock of assets in the economy, held by domestic residents, and $I_{t}$ is the gross investment in period $t, I_{t}=K_{t+1}-K_{t}$.

We assume no speculative arbitrage gains through the operations of the intermediary, since in a deterministic model such a specification would be implausible. Hence, net profits of the intermediary are zero.

Under the current setup, each period the government deficit $D_{t}$ is financed by newly issued bonds, whose only buyer is the intermediary. The intermediary itself creates a market for both the domestic and foreign savers. Eq. (7) narrates the crowding-out effects of government's

\footnotetext{
$\overline{11}$ We resort to this specification to avoid making ad hoc assumptions regarding the public sector's investment decisions.
} 
debt instruments (GDIs) on the loanable funds market. Assuming that all assets are perfect substitutes, the newly issued debt directly constrains the funds available for new investments in physical capital.

\subsection{Foreign trade and equilibrium conditions}

The model, under the assumption of the small open economy, regards world prices (PW) as exogenously given. Domestic imports and exports functions are derived through the socalled Armingtonian commodity specification of the traditional CGE modeling exercises. Accordingly, within each financial sector, the domestically produced good (DC), imports $(M)$ and exports $(E)$ are differentiated by way of imperfect substitutability.

The aggregate demand for imports and export earnings determination lead to the following balance of payments equation:

$$
S_{t}^{F}=\mathrm{BI}_{t+1}^{F}-\mathrm{BI}_{t}^{F}=\mathrm{PW}_{t} M_{t}+r_{t} \mathrm{BI}_{t}^{F}-\mathrm{PW}_{t} E_{t}
$$

Here, $\mathrm{BI}_{t}^{F}$ is the debt of the intermediary held by foreigners and $S_{t}^{F}$ is their savings. The "rest of the world" earns interest on the debt it holds each period.

Finally, in order to ensure that the model is in macro-equilibrium, the following resource constraint is introduced:

$$
K_{t}+B_{t}=\sum_{g} a_{g, t} n_{g, t}+\mathrm{BI}_{t}^{F}
$$

This constraint states that, at every period, the sum of physical capital and government debt has to be equal to private wealth and foreign debt $\left(\mathrm{BI}_{t}^{F}\right)$. Thus, since in each period the sum of physical investments equals to additions to the capital stock, Eq. (9) shows, how in equilibrium, the debt servicing requirement of the government constrains the economy's capacity to generate investments, therefore capital accumulation, and real growth. This is one of the key features of the model to capture the main spirit of the current IMF program in Turkey.

\section{Policy analysis}

\subsection{Calibration and the baseline growth path}

The generational distinction brings a complexity to the model that forces it exempt from analytical treatment. With the assumption of perfect foresight, all equations ought to be solved simultaneously, and this can be achieved only through numerical simulations. We first calibrate the model to a macroeconomic dataset, which is considered as relative equilibrium of the Turkish economy. We then generate a baseline simulation path that will serve as a benchmark where policy alternatives and exogenous shocks are to be contrasted. This procedure follows a number of steps.

First, we used the macro and the input-output data for 1990 and calibrated the "structural" parameters of the model, such that the model reproduces the historical data as its "solution". Moreover, in this step we also reproduce a typical representative generation's life-cycle 
Table 3

Calibration results

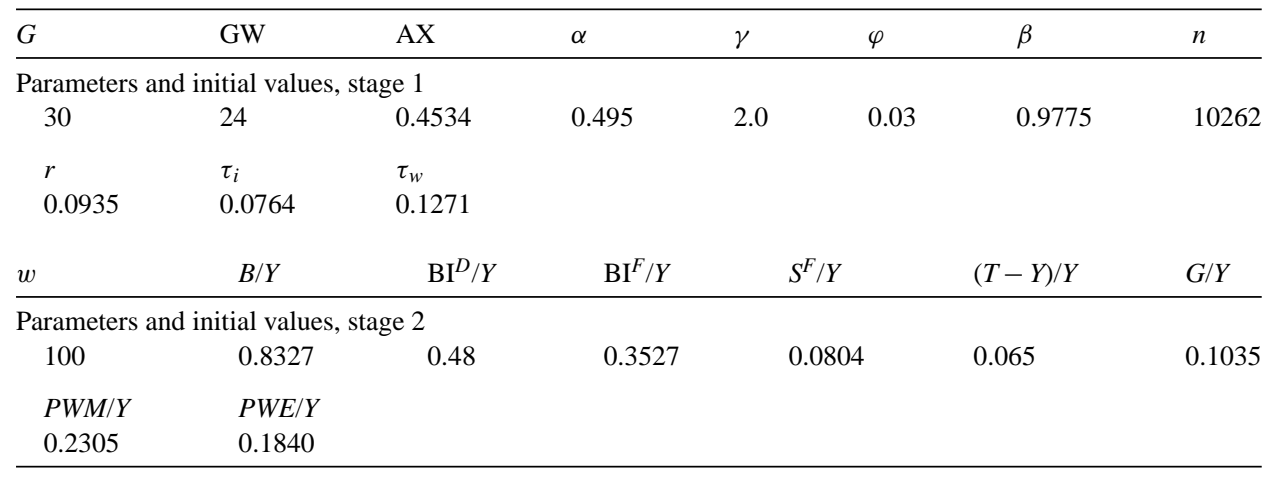

consumption and asset accumulation behavior. The calibration strategy that is followed at this stage basically takes the aggregate supply and demand-side values from the data set (such as output, aggregate private consumption, interest payments on public debt) and determines the parameters, which satisfy all the equilibrium and accounting conditions of the model. The model is calibrated with a given amount of foreign debt at this initial equilibrium growth path. ${ }^{12}$ We report the calibrated and assumed values of the taste and technology parameters in Table 3.

The second step in producing a benchmark economy is to bring the economy to the baseyear period (representing 2002-2003 in the model). To be able to reproduce the historically realized trajectory of the macroeconomic variables-the public sector balances in particular, we shocked the model by imposing the realized increase in public expenditures over the decade. ${ }^{13}$ As we reached the base-year under the shock, we calibrated the variables and parameters that underlie the debt structure of the Turkish government.

The calibrated base-year value of total debt stock to GDP is $83.3 \%$. The domestic debt constitutes $57.6 \%$ of this sum, while the rest is the foreign debt stock. Once the composition of government debt is known, it is easy to generate the amount of foreign savings needed to finance the base-year current account deficit.

Next we study the specifics and the expected macro economic consequences of the current austerity program, TSEP, as implemented under close IMF supervision. The distinguishing characteristic of the simulation is the attainment of primary surplus targets as set out during the official implementation of the program. Given the focus of the current austerity program on attaining significant fiscal surpluses on the non-interest budget, we will distinguish this

\footnotetext{
12 As Buiter (1981) shows, current account deficit is possible along a balanced growth path in a one-good OLG model.

${ }^{13}$ In this exercise we need to impose larger increases than what has been realized in the Turkish government expenditures through 1990s in order to come up with the given debt/GDP ratios for the base year. In our model, the real interest rate is the marginal product of physical capital, which is surely smaller than the historically realized, premium-inclusive financial interest rate observed in Turkey during 1990s. For a more detailed account, see Başçı and Ekinci (2002).
} 
scenario as the "Primary Surplus Program" (PSP). This scenario will further serve as a benchmark simulation path against which we shall ask and compare the results of our "what if" questions. In line with the official targets outlined in Section 3 above, we utilize the model to create a permissible level of government expenditures (net of interest payments) to create a pre-determined level of primary surplus (amounting to $6.5 \%$ for the first 5 periods, and then gradually decreasing it to reach to $1.6 \%$ in the long-run).

Throughout our simulation analysis we assume no further policy shocks and do not admit any changes in the tax rates. Furthermore, no trade shocks are envisaged and we regard the world terms of trade unchanged.

The macro and fiscal results of the scenario are given in the upper panel of Table 4. With an average interest rate of $10.1 \%$, and an average output growth rate of $4.5 \%$, the model predicts a gradual decrease in the ratio of total debt stock to output, reaching to $76.4 \%$ during the 5 th period (year 2012-2013) and 72.2\% during the 10th period (20222023).

Thus, at the outset, the program succeeds in containing the explosive dynamics of debt accumulation; yet, we nevertheless observe an inertial response in the path of the debt to GDP ratio over the medium run. Even though the structure of our analytical model precludes us from making definitive forecasts into the future, the simulation exercise highlights a set of points of vulnerability regarding debt dynamics of the Turkish public sector. First and foremost, we find that the stature of the real rate of interest continues to exert significant burden on the government's ability to administer its debt obligations. Observe that in the absence of any modeling of uncertainty and risk, the model's (endogenous) solution of the interest rate is determined entirely by the real marginal product of capital. This rate, being driven exclusively by the supply of physical capital, signals that the cost of capital remains significantly high even in the absence of currency and/or financial risk. This result is ultimately the outcome of the historically low private saving propensity.

The model results suggest that private savings remain on the order of $20 \%$ of the GDP over the simulated path. Coupled with the fact that savings generation capacity of the public sector is actually in the negative range (see Table 1), the realized gap in the aggregate savings funds necessitate increased dependence on foreign savings, i.e., the external deficit tends to widen over the PSP scenario. The model results disclose an increase in the ratio of foreign savings (external deficit) to GDP to $15.6 \%$ by the 10th period (2022-2023) from its base value of $8.1 \%$ in $2002 / 2003$.

Under these conditions fixed investments can hardly be maintained and the rate of growth of physical capital stock proceeds at a significantly low pace. This fact seems to play a pivotal role in the sluggish behavior of the production capacity. In addition to all above, the contraction of the public sector's non-interest expenditures dampens the rate of growth of aggregate demand and, through the classic Keynesian multiplier mechanism, contributes to the sluggish response of output growth.

On the fiscal side we further observe that the government's total tax revenues as a ratio to the GDP displays a slightly decreasing pattern, reaching to $15.6 \%$ during the 10 th period, 
Table 4

\begin{tabular}{|c|c|c|c|c|c|c|c|c|}
\hline & \multicolumn{8}{|c|}{$6.5 \%$ Primary surplus, standard scenario } \\
\hline & \multicolumn{8}{|l|}{ Period } \\
\hline & $1(2004-2005)$ & $2(2006-2007)$ & $3(2008-2009)$ & $4(2010-2011)$ & $5(2012-2013)$ & $8(2018-2019)$ & $9(2020-2021)$ & $10(2022-2023)$ \\
\hline \multicolumn{9}{|l|}{ As a ratio to GDP } \\
\hline Private consumption & 0.6322 & 0.6354 & 0.6377 & 0.6391 & 0.6408 & 0.6419 & 0.6410 & 0.6397 \\
\hline Private savings & 0.2448 & 0.2332 & 0.2223 & 0.2122 & 0.2029 & 0.1777 & 0.1703 & 0.1634 \\
\hline Total investment & 0.3133 & 0.3113 & 0.3103 & 0.2951 & 0.2946 & 0.2969 & 0.2941 & 0.2966 \\
\hline Capital stock & 4.0526 & 4.1271 & 4.1997 & 4.2707 & 4.3344 & 4.5196 & 4.5804 & 4.6391 \\
\hline \multicolumn{9}{|l|}{ Fiscal balances } \\
\hline Total debt stock & 0.8238 & 0.8079 & 0.7901 & 0.7705 & 0.7644 & 0.7395 & 0.7288 & 0.7218 \\
\hline Primary balance & 0.0650 & 0.0650 & 0.0650 & 0.0650 & 0.0650 & 0.0505 & 0.0505 & 0.0450 \\
\hline $\begin{array}{l}\text { Government expenditures } \\
\text { (net of interest payments) }\end{array}$ & 0.1013 & 0.1001 & 0.0988 & 0.1126 & 0.1115 & 0.1080 & 0.1117 & 0.1105 \\
\hline Government taxes & 0.1663 & 0.1651 & 0.1638 & 0.1626 & 0.1615 & 0.1580 & 0.1567 & 0.1555 \\
\hline Interest rate ${ }^{\mathrm{a}}$ & 0.1071 & 0.1052 & 0.1034 & 0.1017 & 0.1002 & 0.0961 & 0.0948 & 0.0936 \\
\hline \multirow{4}{*}{$\begin{array}{l}\text { Average wage income index } \\
\quad(2002-2003=100)\end{array}$} & 104.953 & 110.043 & 115.308 & 120.733 & 126.168 & 143.642 & 149.905 & 156.347 \\
\hline & \multicolumn{8}{|c|}{$6.5 \%$ Primary surplus, lower growth rate } \\
\hline & \multicolumn{8}{|l|}{ Period } \\
\hline & $1(2004-2005)$ & $2(2006-2007)$ & $3(2008-2009)$ & $4(2010-2011)$ & $5(2012-2013)$ & $8(2018-2019)$ & $9(2020-2021)$ & $10(2022-2023)$ \\
\hline \multicolumn{9}{|l|}{ As a ratio to GDP } \\
\hline Private consumption & 0.6715 & 0.6874 & 0.7035 & 0.7194 & 0.7363 & 0.7837 & 0.7983 & 0.8131 \\
\hline Private savings & 0.2057 & 0.1817 & 0.1575 & 0.1334 & 0.1094 & 0.0393 & 0.0166 & -0.0060 \\
\hline Total investment & 0.2740 & 0.2592 & 0.2443 & 0.2146 & 0.1988 & 0.1546 & 0.1312 & 0.1175 \\
\hline Capital stock & 4.1028 & 4.2282 & 4.3585 & 4.4905 & 4.6180 & 4.9784 & 5.0929 & 5.2010 \\
\hline \multicolumn{9}{|l|}{ Fiscal balances } \\
\hline Total debt stock & 0.8387 & 0.8396 & 0.8421 & 0.8455 & 0.8658 & 0.9369 & 0.9645 & 1.0054 \\
\hline Primary balance & 0.0650 & 0.0650 & 0.0650 & 0.0650 & 0.0650 & 0.0505 & 0.0505 & 0.0450 \\
\hline Government expenditures & 0.1013 & 0.1002 & 0.0990 & 0.1128 & 0.1117 & 0.1085 & 0.1173 & 0.1161 \\
\hline Government taxes & 0.1663 & 0.1652 & 0.1640 & 0.1628 & 0.1617 & 0.1585 & 0.1573 & 0.1561 \\
\hline Interest rate & 0.1058 & 0.1027 & 0.0996 & 0.0967 & 0.0940 & 0.0872 & 0.0852 & 0.0835 \\
\hline Average wage income & 103.088 & 105.895 & 108.257 & 110.237 & 111.682 & 114.538 & 115.018 & 115.181 \\
\hline
\end{tabular}


Table 4 (Continued)

\begin{tabular}{|c|c|c|c|c|c|c|c|c|}
\hline & \multicolumn{8}{|c|}{$6.5 \%$ Primary surplus, higher growth rate } \\
\hline & \multicolumn{8}{|l|}{ Period } \\
\hline & $1(2004-2005)$ & $2(2006-2007)$ & $3(2008-2009)$ & $4(2010-2011)$ & $5(2012-2013)$ & $8(2018-2019)$ & $9(2020-2021)$ & $10(2022-2023)$ \\
\hline \multicolumn{9}{|l|}{ As a ratio to GDP } \\
\hline Private consumption & 0.6135 & 0.6100 & 0.6047 & 0.5978 & 0.5906 & 0.5655 & 0.5562 & 0.5473 \\
\hline Private savings & 0.2634 & 0.2583 & 0.2549 & 0.2529 & 0.2522 & 0.2528 & 0.2536 & 0.2547 \\
\hline Total investment & 0.3320 & 0.3367 & 0.3433 & 0.3365 & 0.3448 & 0.3736 & 0.3741 & 0.3841 \\
\hline Capital stock & 4.0437 & 4.0952 & 4.1389 & 4.1758 & 4.2004 & 4.2725 & 4.2992 & 4.3242 \\
\hline \multicolumn{9}{|l|}{ Fiscal balances } \\
\hline Total debt stock & 0.8197 & 0.7960 & 0.7687 & 0.7376 & 0.7181 & 0.6468 & 0.6191 & 0.5996 \\
\hline Primary balance & 0.0650 & 0.0650 & 0.0650 & 0.0650 & 0.0650 & 0.0505 & 0.0505 & 0.0450 \\
\hline Government expenditures & 0.1013 & 0.1000 & 0.0988 & 0.1125 & 0.1113 & 0.1078 & 0.1165 & 0.1154 \\
\hline Government taxes & 0.1663 & 0.165 & 0.1638 & 0.1625 & 0.1613 & 0.1578 & 0.1565 & 0.1554 \\
\hline Interest rate & 0.1074 & 0.1060 & 0.1049 & 0.1040 & 0.1034 & 0.1016 & 0.1010 & 0.1004 \\
\hline Average wage income & 105.488 & 111.661 & 118.455 & 125.941 & 134.065 & 163.060 & 174.468 & 186.693 \\
\hline
\end{tabular}


starting from a value of $16.6 \% .^{14}$ As government expenditures (net of interest payments) is the only variable that adjusts to reach the pre-determined level of primary surplus targets, we observe a parallel movement of this variable with the government tax revenues, as well.

\subsection{Checking for vulnerability of the PSP path}

We now utilize the laboratory characteristics of the OLG set-up, and check for the sensitivity of the PSP to exogenous shocks on growth. We first introduce a "low growth" scenario, where we let the growth rate of the total output to fall below the rate of growth of the benchmark path recognized for the official PSP. Formally, we exogenously reduce the rate of technological improvement for the first 5 periods, and then allow it to gradually reach the equilibrium level in the long-run (after period 30). Versions of this scenario have become a part of the routine sensitivity analysis of what we refer to as partial equilibrium "accounting exercises" conducted by many finance institutions as well as the official government bodies. Arguably, given the broader, general equilibrium context of our model, our reported results provide an interesting contrast to such partial equilibrium exercises.

We find that, such an adverse shock on the rate of technological improvement causes the average growth rate of total output to be reduced to $1.3 \%$ for the first 10 periods. Yet, we keep the primary surplus target unchanged. The middle panel of Table 4 emphasizes selected variables as a ratio to GDP, while Table 5 pictures deviations from the benchmark path (the official program). The rates of growth envisaged under the alternative scenarios are further contrasted in Fig. 2.

Given that the interest rate (marginal product of physical capital) attains a value of $9.4 \%$ on average for the first 10 periods, adherence to the program target of $6.5 \%$ of primary surplus immediately leads to a reversal of the path of the total debt/output indicator. This ratio increases significantly reaching to a value of $100.5 \%$ over 2022-2023. This amounts to a $2.6 \%$ higher level of aggregate debt stock in comparison to the benchmark economy, and to $26.3 \%$ lower level of GDP by that period. Fig. 3 portrays the contrasting paths of the debt/GDP ratio under the simulated growth shocks.

The adverse shock on the productivity growth rate of the labor-augmenting technology directly causes a decrease in the aggregate effective labor. Similarly, the total capital stock shows significant deviation from the base-run, although capital stock-output ratio gradually rises (see Fig. 4). This is due to the fact that foreign savings increase (current account deficit widens even further) at a higher rate in comparison to the rate of growth of GDP during the period of transition. Furthermore, with relatively lower level of interest rate and lower average wage earnings, disposable income of the private sector shows considerable reduction. From Table 5 total profit and wage income show a negative deviation on the order of $30 \%$ with respect to the PSP scenario.

From the point of view of "fiscal balances and debt sustainability", one of the most relevant questions to ask is what should the level of primary surplus be in order to sustain the total debt stock under the adverse conditions of low growth. That is, given the

\footnotetext{
14 The reason why we do not observe a constant ratio despite proportional taxes is that during transition, the growth rate of labor input, labor income, capital stock and output are different.
} 
Table 5

General equilbrium results (deviations from the primary surplus program)

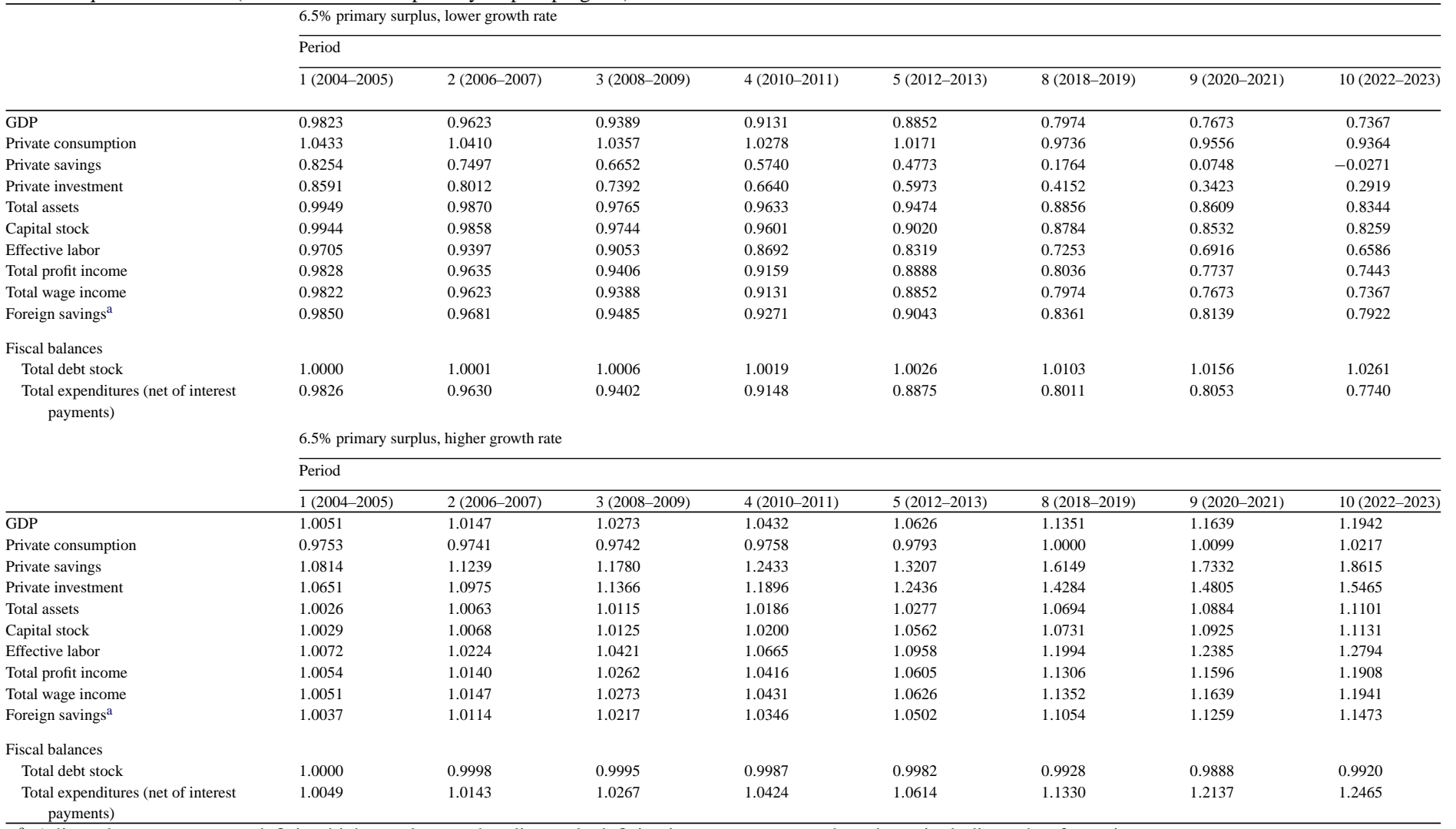

${ }^{a}$ Adjusted current account deficit which equals: merchandise trade deficit + interest payments abroad, not including other factor incomes 


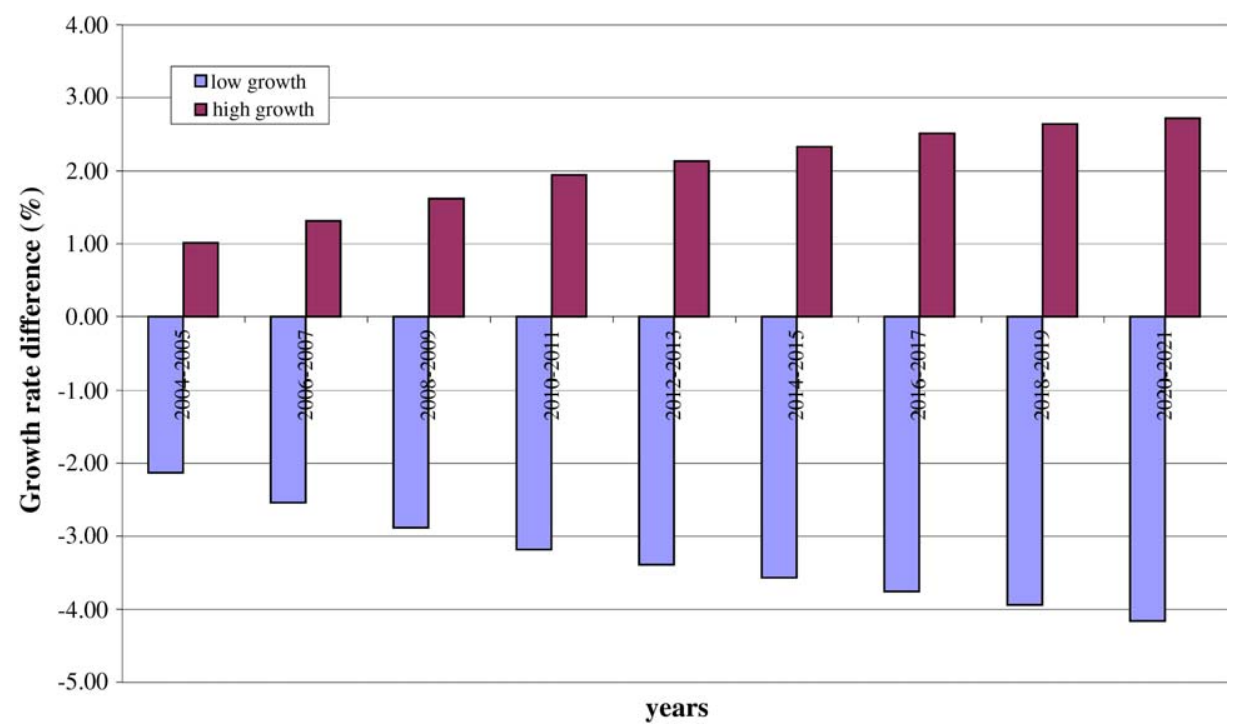

Fig. 2. Growth rate difference of GDP w.r.t. "Primary Surplus Program".

warranted (sustainable) path for the debt to GDP ratio as generated under the official PSP scenario, by how much should the primary surplus be increased? To answer this question we implement a "constrained" simulation of our model and calculate numerically the necessary ratio of the primary surplus to GDP that will hold the debt dynamics in the

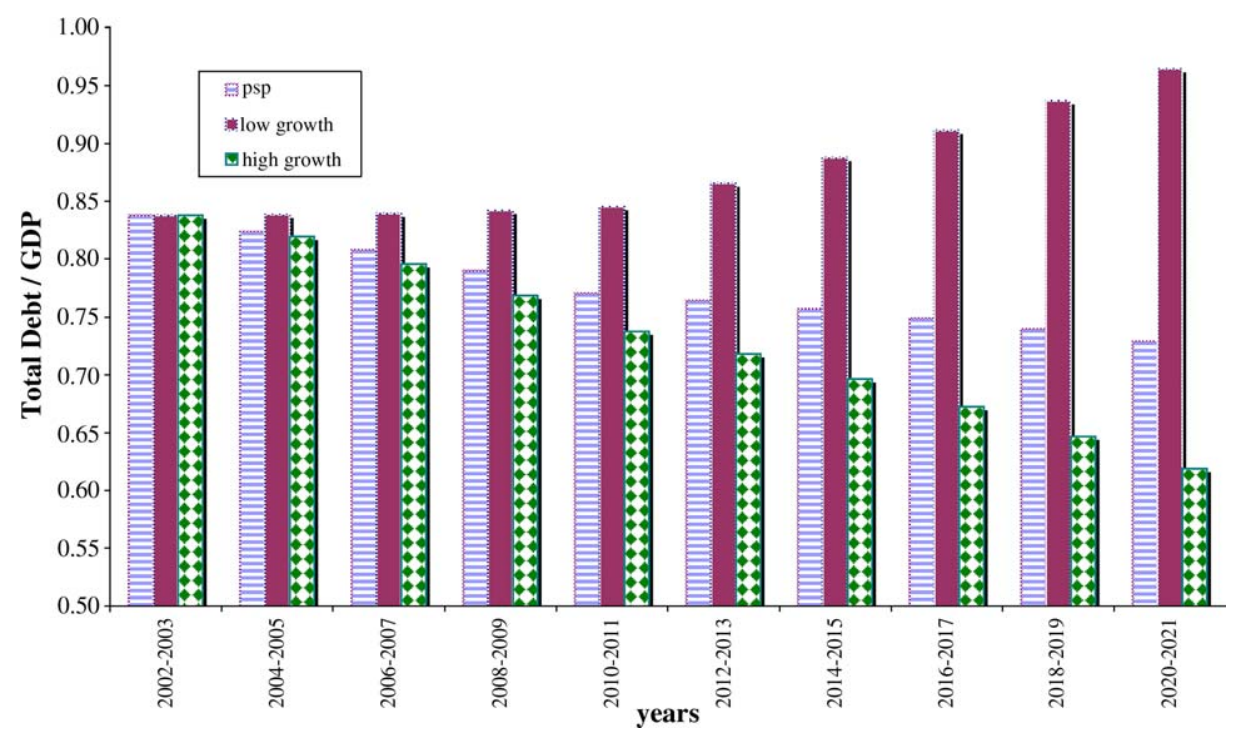

Fig. 3. Total debt as a ratio to GDP. 


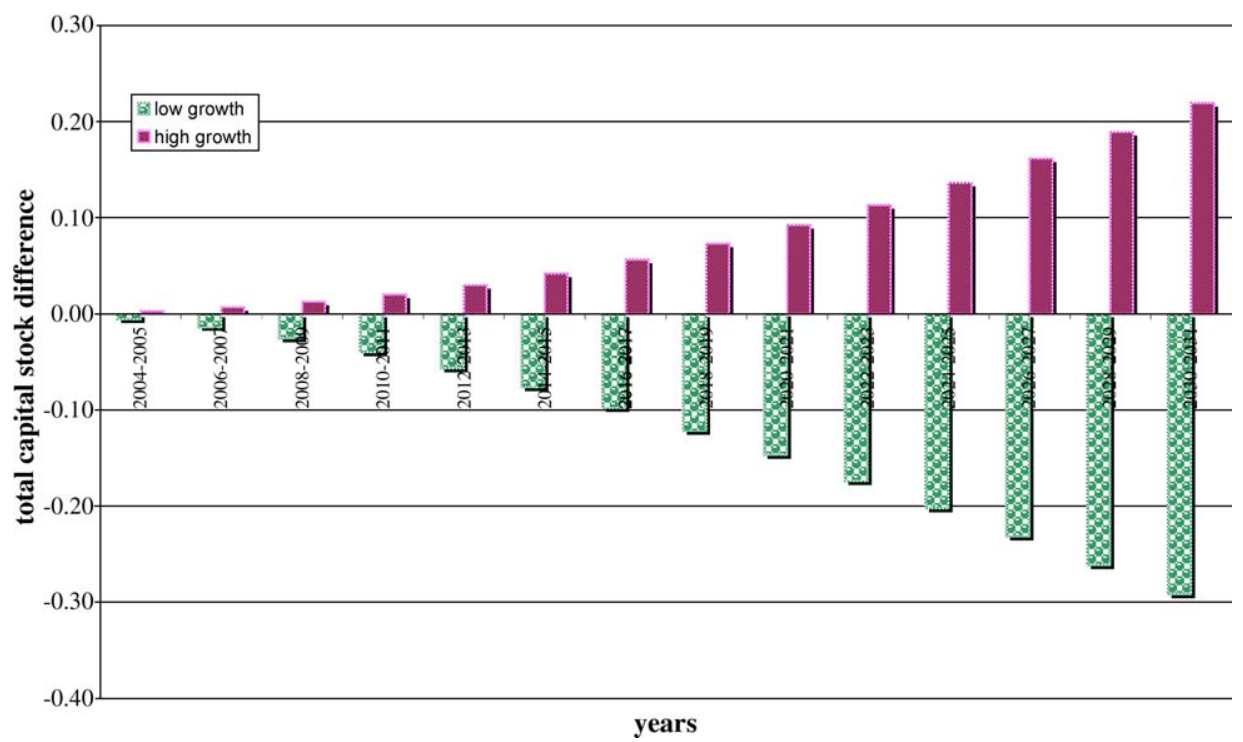

Fig. 4. Total capital stock accumulation (deviations from the Primary Surplus Program).

same path as in the official benchmark equilibrium. We illustrate the simulated result in Fig. 5.

The model results suggest that in order to keep the debt to GDP ratio at its officially planned path, the public sector primary surplus ought to be increased to $8.2 \%$ as a ratio to the GDP for four consecutive periods (until 2010), and then would have to remain by approximately 2 percentage points higher over the rest of the planning horizon. Thus, our

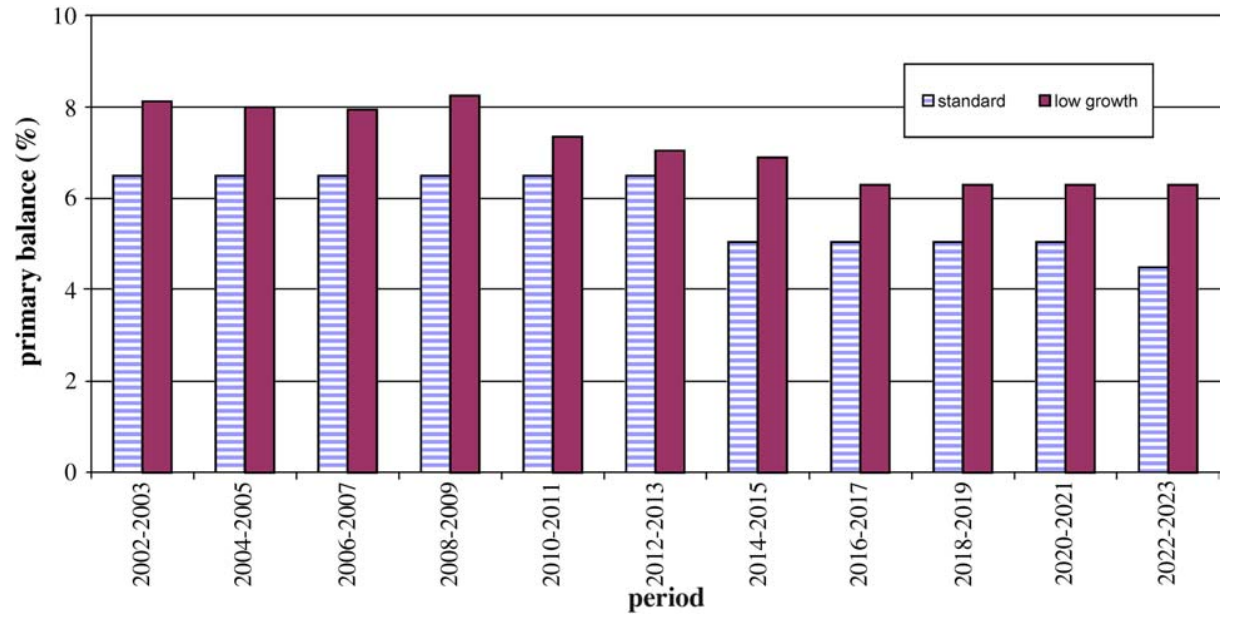

Fig. 5. Necessary primary balance to GDP ratio for debt sustainability under the "low growth" scenario. 


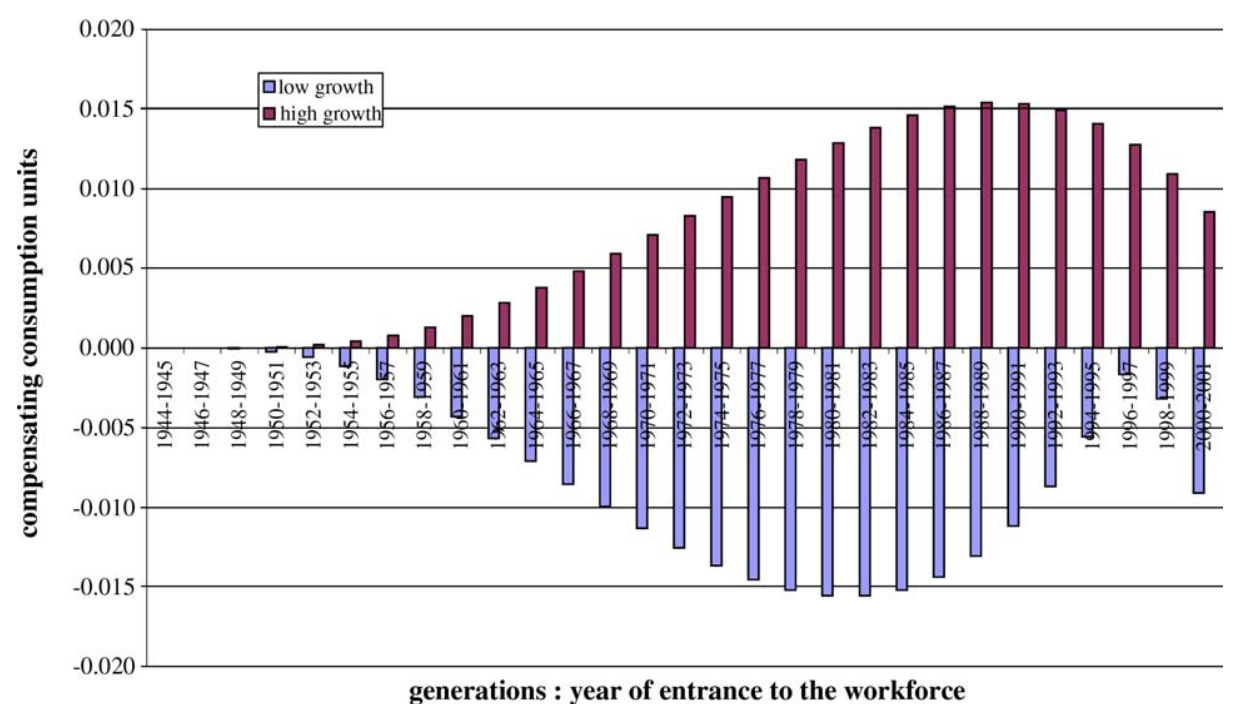

Fig. 6. Welfare analysis for generations entering the workforce before base year.

sensitivity analysis suggests that a decline of the growth rate by 3.2 percentage points on average would require an increase in the primary surplus to GDP ratio by roughly 1.7 percentage points. It remains an open question whether the Turkish economy would be able to absorb such a contraction of public expenditures over such an extended period, and whether it is politically/socially realistic to expect the private households to endure the consequent deterioration of public services for that long. ${ }^{15}$

We finally report on the social welfare consequences of our scenarios. As a measure of this metric, we use the utility in "compensating consumption units" based on the methodology used by King and Rebelo (1990). Denote $U_{t}\left(\left\{c_{g}\right\}_{g=1}^{30}\right)$ as the lifetime utility of an agent entering the workforce at time $t$, by following a consumption path $\left\{c_{g}\right\}_{g=1}^{30}$ under the benchmark economy. The welfare gain (or loss) associated by the shock $\theta$ is such that $U_{t}\left(\left\{c_{g}(1-\theta)\right\}_{g=1}^{30}\right)=U_{t}\left(\left\{c_{g}^{\prime}\right\}_{g=1}^{30}\right) .\left\{c_{g}^{\prime}\right\}_{g=1}^{30}$ is the path of consumption of the agent after the shock. Fig. 6 shows the welfare loss (or gain) of past generations (generations entering the workforce before base year, 2002-2003) and Fig. 7 shows the deviation in the welfare of future generations under low and high growth scenarios. As followed from the figures, a high growth scenario would increase the welfare of both the present and future generations. The welfare increase in future generations would be much comparable since these generations are the ones that will totally benefit from the "higher growth rate". On the other hand, the "adverse growth shock" would also put much burden on the future generations to enter the workforce.

\footnotetext{
15 On the other hand, given a sufficiently optimistic stance, one can also fiction an exogenous positive shock to the rate of technological change. For comparison, we briefly report on the behavior of the model in response to a positive technological shock on effective labor. We report our results on the last panel of Tables 4 and 5, and portray in Figs. 2-4.
} 


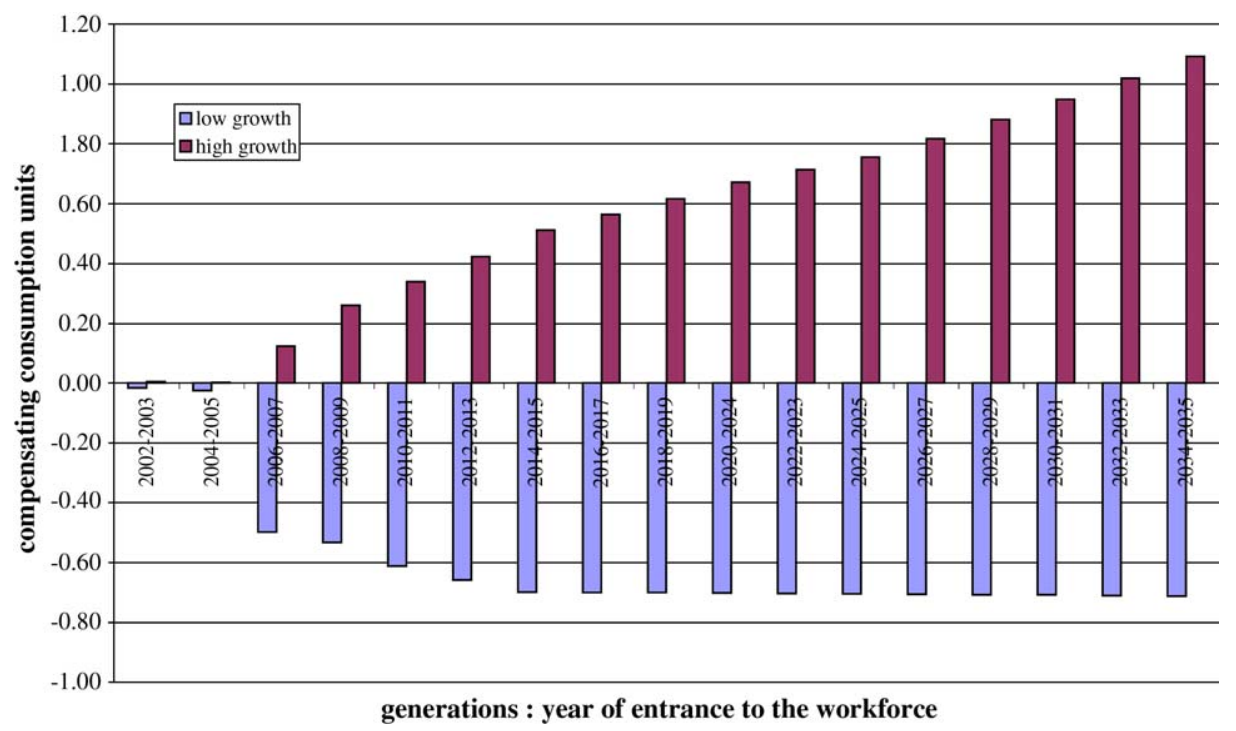

Fig. 7. Welfare analysis for generations entering the workforce after base year.

\section{Concluding comments}

In this paper, we studied the welfare and growth implications of the Turkish fiscal austerity program as directed and supervised by the IMF. The program, referred as the "Turkey's Transition to a Strong Economy", was advanced in May 2001 and extended to be in operation at least until 2006. The program is criticized heavily in that it gives priority to targets on fiscal debt rather than growth, and implements an implicit preference for finance over industry. Furthermore, the program is accused of lacking credible public support and of general ignorance on its social welfare implications.

In an attempt to investigate the growth and welfare consequences of the current austerity program, as well as its sensitivity (vulnerability) to various technological shocks, we have taken a general equilibrium framework and utilized and OLG model of growth, calibrated to Turkish data over 1990s. Our results show that the path of aggregate public debt as a ratio to GNP displays significant degree of inertia and would be brought down only gradually and slowly. Moreover, checking for the vulnerability of the official program path to possible exogenous shocks on growth (technological change), we find that adherence to the given program targets on fiscal austerity immediately leads to a reversal of the path of the total debt/output indicator. In this case, the primary surplus that would be needed to keep the debt to GNP ratio at its officially planned path rises by at least two percentage points over the medium-run.

These results deliberately raise concerns over the reliability of the hypothesis of expansionary fiscal contraction in the Turkish context. ${ }^{16}$ Moreover, it remains a crucial question

\footnotetext{
16 Likewise, the Stability and Growth Pact and the Maastricht Treaty which roughly constrains the EU countries and its candidates by a government deficit not exceeding 3\% of GDP and a public debt to GDP ratio not exceeding
} 
whether the Turkish economy will not only be able to absorb such a contraction of the public expenditures (especially public investments on social capital, including health and education expenditures) over such extended periods, but will be able to generate a sustained path of growth, in a country where historically growth has been dependent on public investments and the anti-poverty policies mostly relied on public social infrastructure.

\section{Acknowledgements}

We are grateful to Jean Mercenier and Marcelle Mérette for their advice and to Oktar Türel, Al Campbell, Cihan Bilginsoy, Korkut Ertürk and to colleagues at Bilkent for their valuable suggestions and comments on earlier drafts of the paper. We have also benefited from discussions with Xinshen Diao and Terry Roe. All usual caveats, of course, do apply.

\section{References}

Agénor, P. R. (2001). Fiscal policy, public debt sustainability, and solvency (lecture notes). World Bank. http://www1.worldbank.org/wbiep/macro-program/agenor/agenor_lectures.htm.

Agénor, P. R., \& Montiel, P. J. (1999). Development macroeconomics (2nd ed.). Princeton, NJ: Princeton University Press.

Akçay, C., Alper, E., \& Özmucur, S. (2002). Budget deficit, inflation and debt sustainability: Evidence from Turkey (1970-2000). Boğaziçi University, mimeo.

Akyüz, Y., \& Boratav, K. (2002). The making of the Turkish financial crisis (UNCTAD Working Paper No. 158, UNCTAD/OSG/DP/158).

Alper, E., \& Öniş, Z. (2003). Emerging market crises and the IMF: Rethinking the role of the IMF in the light of Turkey's 2000-2001 financial crises. Canadian Journal of Development Studies, 24(2), 255-272.

Auerbach, A. J., \& Kotlikoff, L. J. (1987). Dynamic fiscal policy. Cambridge, UK: Cambridge University Press.

Bascard, G., \& Razin, A. (1997). Indonesia's fiscal position: Sustainability issues. In J. Hicklin, D. Robinson, \& A. Singh (Eds.), Macroeconomic issues facing ASEAN countries. Washington: International Monetary Fund.

Başç1, E., \& Ekinci, M. (2002). Bond premium in Turkey: Inflation risk or default risk? (Working Paper, No. 02-07). Department of Economics, Bilkent University.

Blanchard, O. J. (1990). Suggestions for a new set of fiscal indicators (OECD Economics and Statistics Department Working Paper, 26531).

Boratav, K., Yeldan, E., \& Köse, A. (2002). Globalization distribution and social policy: Turkey 1980-1998. In L. Taylor (Ed.), External liberalization and social policy. London and New York: Oxford University Press.

Buiter, W. H. (1981). Time preference and international lending and borrowing in an overlapping-generations model. Journal of Political Economy, 89, 769-797.

Buiter, W. H. (2003). Two naked emperors? Concerns about the stability and growth pact and second thoughts about central bank independence. In IFS Annual Lecture.

Buiter, W. H., \& Grafe, C. (2002). Reforming EMU's fiscal policy rules: Some suggestions for enhancing fiscal sustainability and macroeconomic stability in an enlarged $E U$. Mimeo.

$60 \%$ are found to be seriously flawed to address the economic realities of the candidate countries regarding their expected future GDP growth rates and their inherited stocks of public sector capital. See Buiter (2003), Marin (2002) and Blanchard (1990). Buiter and Grafe (2002) propose an alternative rule, based on a strong form of tax smoothing. In the Turkish context, in an OLG model of endogenous growth, Voyvoda and Yeldan (2005) show that the current fiscal program based on the primary surplus objective suffers from serious trade-offs on growth and fiscal targets, and that an alternative public expenditures program with the objective of reviving public funds for productive infrastructure, supported by a tax reform, is likely to produce superior economic performance. 
Buiter, W. H., \& Patel, U. R. (1992). Debt, deficits and inflation: An application to the public finances of India. Journal of Public Economics, 47, 171-205.

Caballé, J. (1998). Growth effects of taxation under altruism and low elasticity of intertemporal substitution. The Economic Journal, 108, 92-104.

Chalk, N., \& Hemming, R. (2000). Assessing fiscal sustainability in theory and practice (IMF Working Paper, No. WP/00/81).

Cizre-Sakallığlu, Ü., \& Yeldan, E. (2000). Politics, society and financial liberalization: Turkey in the 1990s. Development and Change, 31(1), 481-508.

Corsetti, G., \& Roubini, N. (1991). Fiscal deficits, public debt and government solvency: Evidence from OECD countries. Journal of Japanese and International Economy, 5(4), 354-380.

Ertugrul, A., \& Selcuk, F. (2002). Turkish economy: 1980-2001. In A. Kibritcioglu, L. Rittenberg, \& F. Selcuk (Eds.), Inflaiton and disinflation in Turkey. Aldershot: Ashgate Pub. Co.

Ertugrul, A., \& Yeldan, E. (2003). On the structural weaknesses of the post-1999 Turkish dis-inflation program. Turkish Studies Quarterly, 4(2), 53-67.

Gerson, P., \& Nellor, D. (1997). Philippine fiscal policy: Sustainability, growth and savings. In J. Hicklin, D. Robinson, \& A. Singh (Eds.), Macroeconomic issues facing ASEAN countries. Washington: International Monetary Fund.

Hviding, K., \& Mérette, M. (1998). Macroeconomic effects of pension reforms in the context of ageing: OLG simulations for seven OECD countries (Technical Report, 201, OECD Working Papers).

IMF. (2000). Turkey: Selected issues and statistical appendix (Country Report No. 00/14).

Keyder, N. (2003). A note on the debt sustainability issue in Turkey (Working Paper, No. 03/02, Ankara). Economic Research Center, Middle East Technical University.

King, R. G., \& Rebelo, S. (1990). Public policy and economic growth: Developing neoclassical implications. Journal of Political Economy, 98, S126-S150.

Konukman, A., Aydın, A., \& Oyan, O. (2000). Türk Kamu Mali Yönetiminin Yeniden Yapılandırılması: Tespit ve Öneriler. In Proceedings of the XV. Turkish Financial Symposium.

Marin, J. (2002). Sustainability of public finances and automatic stabilization under a rule of budgetary discipline (European Central Bank Working Paper, No. 193).

Mérette, M. (1998). The tax effect of debt reduction on intergenerational equity and growth: The case of Canada. Mimeo.

Özatay, F. (1999). The 1994 currency crisis in Turkey. Policy Reform, 1(1), 1-26.

Polak, J. (1997). The IMF monetary model at forty (IMF Working Paper, WP/97/49, Washington, DC).

San, E. (2002). Sustainability of fiscal policy: The case of Turkey. Unpublished MS thesis, Middle East Technical University.

Türel, O. (1999). Restructuring the public sector in post-1980 Turkey: An assessment (ERC Working Papers, No: 99/6). Middle East Technical University.

Undersecretariat of Treasury. (2003). Public debt management report.

Voyvoda, E., \& Yeldan, E. (2005). IMF programs, fiscal policy and growth: Investigation of macroeconomic alternatives in an OLG model of growth for Turkey. Comparative Economic Studies, 47, 41-79.

World Bank. (2000, September). Turkey-Country economic memorandum-Structural reforms for sustainable Growth (Vols. I and II) (Report No.20657TU), Washington, DC.

Yeldan, E. (2002). On the IMF-directed disinflation program in Turkey: A program for stabilization and austerity or a recipe for impoverishment and financial chaos? In N. Balkan \& S. Savran (Eds.), The ravages of neoliberalism: Economy, society and gender in Turkey. New York: Nova Science Pub. 